$\mathbb{T}$ Periodica Polytechnica

Social and Management

Sciences

25(2), pp. 127-140, 2017

https://doi.org/10.3311/PPso.10644

Creative Commons Attribution (i)

\section{Energy Export Potential in the Caspian Region and Its Impact on EU Energy Security}

\author{
Aigerim Ibrayeva $^{1 *}$, Raikhan Tashtemkhanova ${ }^{1}$, Aigerim Ospanova $^{1}$, \\ Baubek Somzhurek ${ }^{1}$, Aiman Azmukhanova ${ }^{1}$
}

RESEARCH ARTICLE

\begin{abstract}
Energy security has emerged in recent years as one of the cornerstones of the European Union's (EU's) foreign policy. The $E U$ is highly dependent on imports of oil and gas, 35 per cent of which comes from Russia. Diversification of energy supplies is thus a key goal for the EU. The Caspian region contains some of the largest undeveloped oil and gas reserves in the world. The intense interest shown by the major international oil and gas companies testifies to its potential. Although the area is unlikely to become "another Middle East", it could become a major oil supplier at the margin, much as the North Sea is today. As such it could help increase world energy security by diversifying global sources of supply. Development of the region's resources still faces considerable obstacles. This study focuses on the countries along the southern rim of the former Soviet Union that are endowed with significant oil and gas resources: Kazakhstan, Turkmenistan and Uzbekistan in Central Asia, and Azerbaijan in Transcaucasia. The Southern Energy Corridor (SEC), which aims to link Caspian Basin and potentially Middle East gas supplies to Europe, is one of the EU's six priority axes of energy infrastructures. Drawing on the external governance literature, this article provides an analysis of the EU's efforts in the wider Black Sea area to increase its energy security. It concludes that despite difficult domestic and geopolitical obstacles, the EU is pushing forward its objective to establish the SEC.
\end{abstract}

\section{Keywords}

Caspian countries, European Union, riparian states, hydrocarbons, Southern Corridor, pipeline, energy security

\footnotetext{
${ }^{1}$ Department of Regional Studies, L.N. Gumilyov Eurasian National University, Astana, Kazakhstan
}

*Corresponding author, e-mail: Aigerimibrayeva7@gmail.com

\section{Introduction}

The dissolution of Soviet Union in 1991 bore three 'energy rich' sovereign states in Central Asia: Kazakhstan, Turkmenistan and Uzbekistan. Their proven conventional natural gas reserves amount to $27.8 \mathrm{tcm}$ (trillion cubic metres), $13.3 \%$ of the world's total. According to the International Energy Agency (IEA), their total production will increase from $143 \mathrm{bcm}$ (billion cubic metres) in 2009 to $265 \mathrm{bcm}$ in 2035, and the region will become an important gas exporter (IEA, 2010). Table 1, presents the Central Asian states proven reserves, production, consumption and net exports in detail. The Central Asian states seek to derive maximum benefit from their rich natural gas reserves. Inheriting the Soviet pipeline network, they have relied on Russia for the bulk of their west-bound gas exports (see Table 2, for Central Asian exports by destination). The Russian dominance on gas transit and the poor access to alternative markets have set value on Central Asian gas. In order to increase revenues from their gas exports, the Central Asian states search for alternative pipeline projects which will diversify their transit routes as well as export markets. However, pipelines carrying Central Asian gas to distant markets have to pass through multiple countries which have their own strategic interests.

There are four major powers striving for potency in Central Asia: Europe and Turkey, led by the USA in the West, Russia in the North, rapidly growing China in the East and Iran seeking to become a regional power in the South. Energy hungry emerging countries in Asia such as India, Pakistan and South Korea also could be added to the list as well. The Ukrainian gas crisis in 2009, has generated a great deal of commentary about European dependence on Russian energy in general and natural gas in particular. The price dispute which led to termination of Russian supplies to Ukraine in June 2014, and the possibility of interruptions of gas supplies to Europe, led to renewed calls for diversification of European gas supplies and reduction of Russian imports. The Caspian is of central interest for European energy security, although the supply chain from the region has been traditionally kept under Russian Federation control. However, for the past decade or so, the EU is becoming increasingly ambitious in planning Caspian pipelines 
that exclude Russian Federation's territory and the Nabucco Pipeline project was in the centre of these strategic efforts for a considerable amount of time. The Caspian is therefore also at a crossroads between grand and conflicting energy interests of the Russian Federation and (Western) Europe. In addition to recouping the losses from energy trade important consequence will therefore be a much tougher competition to attract investments in the future, inevitably resulting in greater concessions made on the invested side which is likely to impact regional stability.

Table 1 Natural gas in Central Asia and Caspian Basin

\begin{tabular}{llllll}
\hline Country & $\begin{array}{l}\text { Production } \\
\text { Bcm }\end{array}$ & $\begin{array}{l}\text { Consumtion } \\
\text { Bcm }\end{array}$ & $\begin{array}{l}\text { Net } \\
\text { exports } \\
\text { Bcm }\end{array}$ & \multicolumn{2}{c}{$\begin{array}{l}\text { Proven } \\
\text { reserves }\end{array}$} \\
\cline { 4 - 6 } & & Bcm & $\%$ \\
\hline Azerbaijan & 16 & 8.8 & 6.6 & 1.1 & 0.6 \\
Kazakhstan & 11.1 & 7.8. & 10.1 & 0.9 & 0.5 \\
Turkmenistan & 65.2 & 30.9 & 24.5 & 17.5 & 9.4 \\
Uzbekistan & 52.0 & 45.3 & 7.9 & 1.1 & 0.6 \\
\hline Total & 144.7 & 92.8 & 42.5 & 20.6 & 11.1 \\
\hline
\end{tabular}

Table 2 Natural gas exports from Central Asia and Caspian Basin

\begin{tabular}{lllll}
\hline Exports to & Azerbaijan & Kazakhstan & Turkmenistan & Uzbekistan \\
\hline Russia & - & 10.9 & 2.8 & 3.3 \\
Iran & 0.24 & - & 7.2 & - \\
China & - & - & 27.7 & $1.5-$ \\
Turkey & 5.3 & - & - & - \\
Others & 2.1 & 0.1 & - & 0.05 \\
\hline
\end{tabular}

(British Petroleum), 2016 b. Statistical Review of World Energy June 2016 Viewed 15 March 2017 〈http://www.bp.com/content/dam/bp/pdf/energyeconomics/statistical-review-2016/bp-statistical-review-of-world-energy2016-full-report.pdf>

By focusing on the EU's goal of achieving greater diversification of energy supplies by importing gas from the Caspian Basin through the Southern Energy Corridor (SEC), the article argues that although there is an underlying tension between the geopolitical realities of the region, and the EU has been able to become a crucial player in the energy security of the region, pushing forward its agenda including the highly geopolitical Nabucco pipeline, the flagship of the SEC. Since the mid-2000s, the institutionalized approach of the EU has become a necessary condition for achieving EU goals at the regional level. Indeed, the article argues that the EU has become a 'regional hub', whereby it creates close cooperation at regional level through the attraction of its market. However, the EU-supported SEC builds upon the oil and gas pipelines supported by the USA in order to prevent Russian monopoly over the Caspian Basin supplies. If the SEC is possible then it is mainly because of the path-dependent processes set off by the east-west corridor, which inextricably linked the international position of Azerbaijan and especially Georgia and Turkey transit role between the Caspian Sea and Europe. Iran is the largest country in the Middle East with the capacity to pursue a serious international agenda. Iran is also located in a strategically significant area in the Middle East. It shares border with seven countries: Afghanistan, Armenia, Azerbaijan, Iraq, Pakistan, Turkey and Turkmenistan.

Its long coastline on the southern edge includes the Persian Gulf waters and beyond the Straits of Hormoz, across from the Arab states of the Gulf Cooperation Council (GCC): Qatar, Saudi Arabia, UAE, Bahrain and Oman. This gives Tehran strategic control over the waterways through which the majority of the world's oil travels. Iran also sits on the Eastern edge of the Middle East region, closer than its neighbors to trade partners in Asia. Consequently, an amicable relationship with Tehran, who could be convinced to act in the common interest of the region, would be highly beneficial for all parties involved (An EU Strategy for relations with Iran..., 2016). Iran has gone from being a consumer of foreign technology and a pure exporter of oil to being an exporter of oil, gas and petroleum products, a manufacturer of petroleum sector equipment as well as a hub for energy connectivity in the region. Country has pipelines connecting with Turkmenistan and Turkey. With 80 million people, historical ties to the Central Asian countries, Iran could be counterweight to the Russia. EU's demand of Caspian gas could be supply through Iran, it is the best and logical option.

This paper has two major aims: first to determine potential and importance in term of hydrocarbons of the countries which are shared Caspian basin. Second to examine the realistic options for reducing European dependence on Russian gas. In so doing it examines the alternative gas options for reducing dependence on Russian gas; it also provides some idea of the possible supplies through the pipelines and the likely competitiveness of Russian versus alternative gas supplies.

The analysis will be based on a mixture of documentary analysis and a review of previous literature. The documents are published by relevant actors, such as the US Energy Information Administration (EIA) and the International Energy Agency (IEA). These documents provide necessary statistical information. This statistical data, in combination with previous literature on the different countries' energy policies will be instrumental to gain a full understanding of the Caspian region's energy security dynamics. The main data sources used are described briefly below. All energy data presented in this paper is based on the lower heating value. Energy Balances are used for general developments in energy demand and supply (i.e. 2013). For import dependence the European Commission - DG Energy 2016 Statistics Database is used. This database includes imports and exports to countries within the EU, by country of origin or destination. 


\section{Profile of the Caspian Basin, the Caspian Water Plateau}

The Caspian is the world's largest enclosed or landlocked body of (salty) water - approximately of the size of Germany and the Netherlands combined. Geographical literature refers to this water plateau as the sea, or world's largest lake that covers an area of $386,400 \mathrm{~km}^{2}$ (a total length of 1,200 km from north to south, and a width ranging from a minimum of $196 \mathrm{~km}$ to a maximum of $435 \mathrm{~km}$ ), with the mean depth of about 170 meters (maximum southern depth is at $1025 \mathrm{~m}$ ). At present, the Caspian water line is some 28 meters below sea level (median measure of the first decade of 21 st century). The total Caspian coastline measures to nearly $7,000 \mathrm{~km}$, being shared by five riparian (or littoral) states (Bajrektarevic, 2003).

The very legal status of this unique body of water is still not solved as to whether the Caspian is a sea or lake. As international law defers lakes from seas, the Caspian should be referred to as the water plateau or the Caspian basin. Interestingly enough, the Caspian is indeed both sea and lake: northern portions of the Caspian display characteristics of a freshwater lake, due to influx of the Volga river, the Ural River and other relatively smaller river systems from the northern Russian Federation.

The inner circle. The so-called "Inner Circle" of the Caspian Basin consists of the five littoral (riparian) states, such as Russian Federation, Islamic Republic of Iran, Azerbaijan, Kazakhstan, and Turkmenistan, sharing the common coastline. They are of asymmetric constellation and could be roughly divided on the traditional two (Russian Federation and

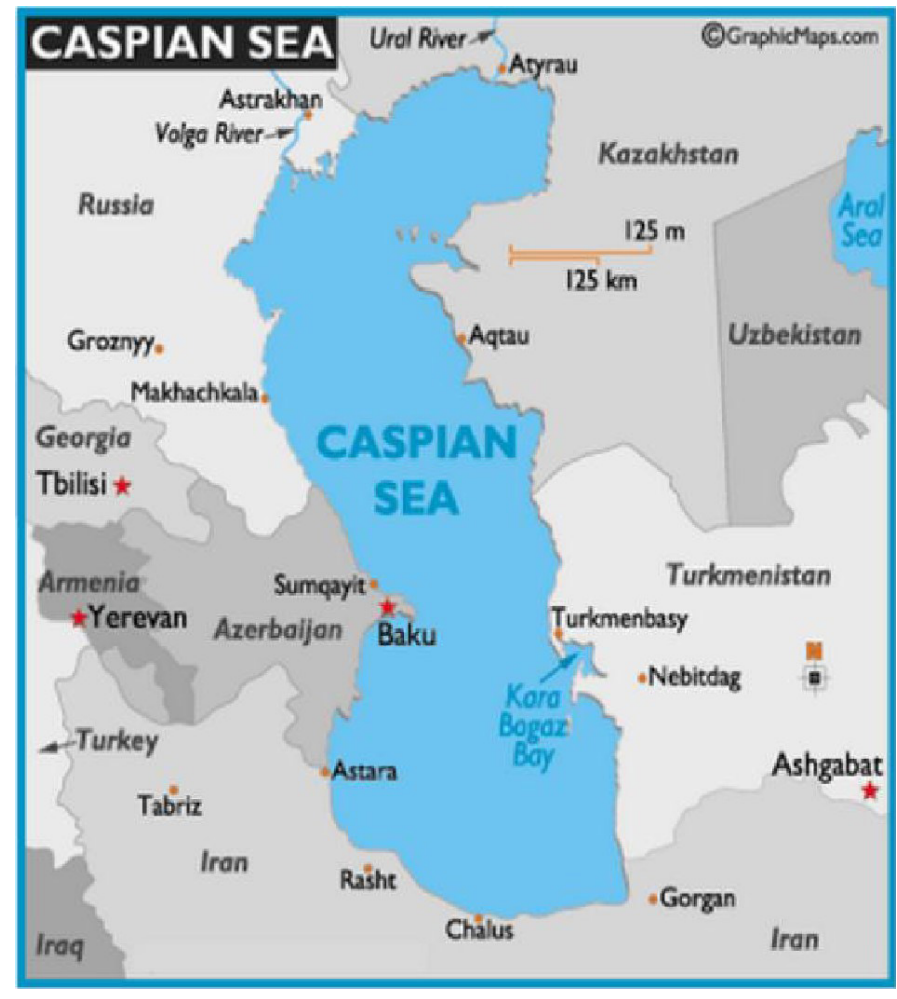

Fig. 1 The Caspian Sea and its hydrogeology Source: World Atlas (n.d.a.), n.p.a.; EVS, 2007, n.p.a

Iran), and the three newcomers (Azerbaijan, Kazakhstan and Turkmenistan). This division also corresponds with the following characteristic: only Iran and Russian Federation have open access to sea.

Table 3 Oil - Total proved reserves

\begin{tabular}{|c|c|c|c|c|c|c|c|}
\hline Country & $\begin{array}{l}\text { At end } 1994 \\
\text { Thousand million } \\
\text { barrels }\end{array}$ & $\begin{array}{l}\text { At end } 2004 \\
\text { Thousand } \\
\text { million barrels }\end{array}$ & $\begin{array}{l}\text { At end } 2013 \\
\text { Thousand } \\
\text { million barrels }\end{array}$ & $\begin{array}{l}\text { At end } 2014 \\
\text { Thousand } \\
\text { Million Tones }\end{array}$ & $\begin{array}{l}\text { Thousand } \\
\text { million } \\
\text { barrels }\end{array}$ & Share of total & $\mathrm{R} / \mathrm{P}$ ratio \\
\hline Azerbaijan & 1.2 & 7.0 & 7.0 & 1.0 & 7.0 & $0.4 \%$ & 22.6 \\
\hline Kazakhstan & 5.3 & 9.0 & 30.0 & 3.9 & 30.0 & $1.8 \%$ & 48.3 \\
\hline Turkmenistan & 0.5 & 0.6 & 0.5 & 0.1 & 0.6 & & 6.9 \\
\hline Uzbekistan & 0.3 & 0.6 & 0.6 & 0.1 & 0.6 & & 24.3 \\
\hline Central Asia total: & 7.3 & 17.2 & 42.6 & 5.1 & 38.2 & $2.2 \%$ & 102.1 \\
\hline
\end{tabular}

BP Statistical Review of World Energy June 2015 bp.com/statisticalreview

Table 4 Natural gas - Total proved reserves

\begin{tabular}{|c|c|c|c|c|c|c|c|}
\hline Country & $\begin{array}{l}\text { At end } 1994 \\
\text { Thousand } \\
\text { million barrels }\end{array}$ & $\begin{array}{l}\text { At end } 2004 \\
\text { Thousand } \\
\text { million barrels }\end{array}$ & $\begin{array}{l}\text { At end } 2013 \\
\text { Thousand } \\
\text { million barrels }\end{array}$ & $\begin{array}{l}\text { At end } 2014 \\
\text { Thousand } \\
\text { million Tones }\end{array}$ & $\begin{array}{l}\text { Thousand } \\
\text { Million barrels }\end{array}$ & $\begin{array}{l}\text { Share of } \\
\text { total }\end{array}$ & $\begin{array}{l}\mathrm{R} / \mathrm{P} \\
\text { ratio }\end{array}$ \\
\hline Azerbaijan & $\mathrm{n} / \mathrm{a}$ & 0.9 & 0.9 & 41.2 & 1.2 & $0.6 \%$ & 68.8 \\
\hline Kazakhstan & $\mathrm{n} / \mathrm{a}$ & 1.3 & 1.5 & 53.2 & 1.5 & $0.8 \%$ & 78.2 \\
\hline Turkmenistan & $\mathrm{n} / \mathrm{a}$ & 2.3 & 17.5 & 617.3 & 17.5 & $9.3 \%$ & \\
\hline Uzbekistan & $\mathrm{n} / \mathrm{a}$ & 1.2 & 1.1 & 38.3 & 1.1 & $0.6 \%$ & 19.0 \\
\hline Central Asia total: & & 5.7 & 21 & 750 & 21.3 & $11.3 \%$ & 166 \\
\hline
\end{tabular}

BP Statistical Review of World Energy June 2015 bp.com/statisticalreview. 


\subsection{Russian Federation}

The Russian Federation controls the north- western shore of the Caspian Sea and only a negligible part of its extensive energy reserves appear to be located in the Caspian Basin. Therefore, Russian Federation has rather adopted a strategy of involvement in the energy business of the other, better-endowed riparian states by means of joint resource development (production revenues) and granting access to the Russian Federation's oil and gas pipeline system (transport revenues). The main players in this field are the state-owned companies Gazprom, Rosneft, and Transneft as well as numerous large private energy enterprises like Lukoil, Sibneft or Yukos (Crandall, 2006)

In light of the loss of economic influence in the Caspian after the dissolution of the Soviet Union, due to the overwhelming preoccupation with preserving the strategic influence in the region, following the sort of "Monroeski doctrine" (Kubicek, 2010).

The Russian Federation's views dramatically shifted in the 2000s from politico- security aspirations to also largely economical. To this end, the Russian Federation turned to bilateral and plurilateral agreements with Caspian littoral countries to secure its economic interests in the basin. With its unique policy, called "common waters, divided bottom", it moved closer to the stances of Kazakhstan and Azerbaijan, following the principle of dividing the seabed into proportional national sectors (therefore, following the UNCLOS principle), while maintaining the common management of the surface water, preserving free navigation and common ecological standards for all littoral states (thus, partly following the lake principle by excluding the international community).

Due to these efforts Russian Federation agreed upon the division of the Northern part of the Caspian with Azerbaijan and Kazakhstan, while still strongly affirming that the five-party consensus continues to be the only way to the final decision on the legal status of the Caspian (Zimnitskaya, 2010; Kapitonov et al., 2017: pp.44-52).
Although this agreement presents a good sign for the future, its major downside is that it is completely dependent on the good relations between littoral states and therefore dependant on the current geopolitical realities of the Caspian. Also, we must consider the defiance of the Islamic Republic of Iran in the solution, since it diminishes its political and economic role in the basin, for it leaves the country with the smallest share and deepest waters.

With this division, the Russian Federation would receive $18,5 \%$ of the Caspian seabed, while Kazakhstan would get 29\%, Azerbaijan and Turkmenistan approximately 19\% and Iran would be left with $14 \%$.The top priority task in Russia's fuel and energy expansion is to create an integrated water and fuel-energy complex in Central Asia (under Russian management). One of the possible ways to carry out this task is to include Tajikistan in the water-energy consortium being created. The Rogun Hydropower Plant-the most powerful in the region-is currently being built in this country. Gazprom will participate in reconstructing and building major gas pipelines, compressor stations, and other infrastructure facilities for Kyrgyzstan's gas complex. It is very possible that Gazprom's main activity in this undertaking will be transiting gas to other countries (China) (Laumulin, 2007). Russia's goal is clear: it wants to strengthen its position as Turkmenistan's main partner in the energy sector and, in so doing, maintain control over the export of Turkmen gas. Ideally, Russia would like to control Turkmen gas in order to guarantee large-scale investments. Today, Turkmenistan is Russia's private ward. RussianTurkmen relations are being built on Russia's management of Turkmen gas assets through Gazprom. The most striking example of Russia's strategy is Gazprom's actions in the region. This company is trying to establish control over the gas flows between Uzbekistan and Kyrgyzstan, as well as between them and foreign markets. In so doing, it is more advantageous for Uzbekistan to sell gas previously intended for Kyrgyzstan to

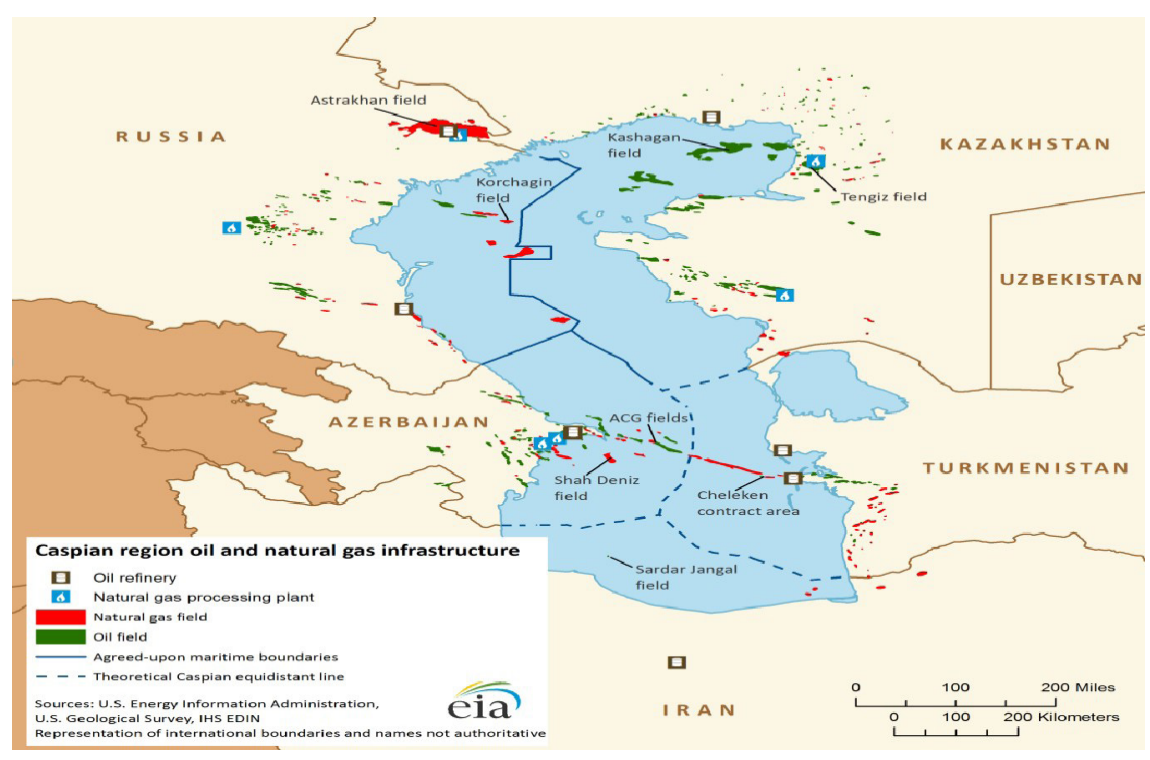

Fig. 2 The proposed and already effective division of the Caspian Basin. Source: EIA (2013a) 
Gazprom. Even though the details of the agreement signed with Kyrgyzstan are not being revealed, it is obvious that the interests of the Russian gas giant in this republic are not related to gas production. Transit of gas through Kyrgyzstan to other countries will become an important factor, since Kyrgyzstan directly borders on China.

Today, the growth rates of production, including those of gas export, from the Central Asian countries is much higher than the rates of modernizing and developing their gas transportation systems. But the main gas artery from the region's states to Russia-the major gas Central Asia-Center pipeline - is currently operating to its limit. This relates to all three gas transportation countries: Turkmenistan, Uzbekistan and Kazakhstan.

Regarding intra-regional relations in general, Russian Federation concerns about the influence of the EU and the US in the Caspian Basin have increased in the recent past due to the eagerness to regain its role as a major power. As for Iran, the historically adverse relations have improved in some areas as the two powers still share a number of mutual interests in the Caspian Basin, for instance the opposition to growing Western interference in regional affairs or the proposed construction of a trans-Caspian (Dekmejian, 2003).

\subsection{Islamic Republic of Iran}

Iran has long had the ambition of becoming a major gas exporter, including to Europe. After many years of mismanagement and underperformance by the previous administration, the Rouhani government has shown a desire for the country to become a major regional and international gas player. Despite ranking among the world's leading oil producers and the second largest producer of natural gas, the Islamic Republic of Iran's share of the local oil and gas reserves is negligible, just as in the case of Russian Federation. Iran holds $16 \%$ of global proven gas reserves BP (Statistical Review of World Energy, 2009). Total gas production in 2014 was $172.6 \mathrm{bcm}$, while domestic consumption stood at $117.6 \mathrm{bcm}$ (Statistical Review of World Energy, 2009). Increased to $131.2 \mathrm{bcm}$ in 2009, consumption did as well $(131.7 \mathrm{bcm})$. More than a third of domestic consumption is used for boosting oil production by pumping gas into maturing oil fields. The share of natural gas with Iranian TPES has increased strongly in the past 10 years. In 2000, the usage of gas for the first time exceeded that of oil. In 2009, natural gas had a share of $57.9 \%$ of total energy supplies, oil was down at $40.8 \%$. Foreign investment is all blocked due to US bilateral sanctions based on the Iran sanctions Act (1996), sanctions imposed by the UN and the EU (Mangott, 2010: pp.45-46). It is in Russia's vital interest that Iran does not turn into a competitor on the EU gas markets. EU and US companies' refusal to trade gas with Iran due to its presumed nuclear weapons program actually serves Gazprom's interest. Russia is keenly interested to direct Iran's future gas exports to consumers in the East-countries such as Pakistan, India or China. It is strategic interest which (partly) explains Gazprom's interest to develop Iranian gas fields-most notably South Pars-and finance Iran's ambitious export pipeline Iran-Pakistan-India.

Iran is considered an attractive export route for oil and gas between Central Asia and Europe, and for oil from both Central Asia and Transcaucasia to the Persian Gulf. It already has a well developed oil and gas infrastructure, including portions of pipeline that could be used for the routes mentioned above or for swaps. By some estimates, an Iranian route could prove significantly cheaper than other proposed pipelines. Iran is also seen as an alternative to transport via Russia. As a Caspian littoral state, Iran will also play an important role in the development of oil and gas resources in parts of the Caspian Sea. All Caspian littoral countries will have to co-operate closely on a number of issues, in particular the protection of the marine environment of the Caspian Sea. Iran, which shares borders with both Turkmenistan and Azerbaijan, is a neighbor with whom the Central Asian and Transcaucasian states are keen to maintain good relations. As an important trading route and partner, Iran already exerts considerable economic and political influence. Its ability to do so could increase significantly if it were to become a major transit route for Central Asian and Transcaucasian energy exports.

Foreign policy priorities have been affected by its past dominance as well as the religious ties with the Republics of Azerbaijan, Kazakhstan and Turkmenistan. However, these newly independent states (NIS) see Islamic Republic of Iran's potential in cheap transit routes for oil and gas. Of the most concern are the Islamic Republic of Iran' s relations with Azerbaijan, hampered due to Azerbaijan's westward cooperation on energy matters (Dekmejian, 2003) and the contradicting positions on defining the legal status of the Caspian. Additionally, the ethnic Azeri minority makes up nearly a quarter of Iran's population. An economically strong and independent Azerbaijan, gaining acknowledgement on the international political stage, could potentially incite the Azeri population in Iran to start its own nationalistic movement and threaten its territorial integrity. To prevent Azerbaijan to rise any further as a global oil player might as well be seen as Iran's strategic goal (Croissant, 1999). Nevertheless, the Islamic Republic of Iran does not generally promote discrimination of the Azeri minority, because their intellectual and economic elite is very well integrated in the Iranian society. A prime example for this is that the father of Ajatolla Khameini is an Azeri (Pivariu, 2014).

There are serious doubts about the viability of the proposed Armenia-Georgia-Ukraine pipeline on economic and - following Russia's annexation of Crimea - geographical grounds. 100 Aside from these options, gas exports to Europe via Turkey using existing infrastructure, seems the most feasible option prior to 2020 .

Irrespective of the technical and geopolitical feasibility of these proposed routes, the second major uncertainty over the 
export of Iranian gas to Europe is the availability of sufficient gas for export markets over and above Iran's domestic requirements. Iran's growing domestic consumption (due to population growth, market expansion, and gas for oil substitution policies, oilfield gas reinjection requirements, and the development of added-value industries) has severely impacted the country's ability to produce sufficient gas for export markets. With the required investment and technology, Iran could increase production capacity to around 210-230 bcm/year by 2018, but this is expected to be mainly allocated to domestic and regional export markets. After meeting growing domestic demand - expected to reach 200-220 bcm/year before 2020 - and supplying gas to the already contracted export markets of the neighboring countries of Turkey (10 bcm/year), Iraq (10 bcm/year), and Oman (5-10 $\mathrm{bcm} /$ year), any gas available for export to the rest of Europe is expected to remain marginal prior to 2020 .

Beyond 2020, depending on how fast Iran can develop the remaining phases of the South Pars and other major discovered gas fields, the country's total production capacity could reach around $350 \mathrm{bcm} /$ year by 2030 (Hassanzadeh, 2014). It is only then that significant exports to Europe can be envisaged, provided that the required infrastructure can be made available. Any direct gas export to Europe requires extensive infrastructure, very significant sources of funding, and long-term agreements which would take Iran and its potential European partners at least 10 year to develop (from Heads of Agreement to first export volumes). The time scale will probably be even longer for LNG exports, due to the complex technical and commercial nature of such projects. Exports of around 10-20 bcm/ year to Europe through Turkey via the existing infrastructure are possible in the 2020s, but it is unrealistic to imagine more substantial volumes becoming a reality until after 2030. This conclusion pre-supposes that the political forces within Iran which oppose exports do not prevail, given that reinjection of gas into oilfields (for secondary and tertiary recovery) and additional investment in petrochemicals can be argued to provide a higher return for the country than gas exports.

\subsection{Azerbaijan}

As a state on the shore of the Caspian Sea, Azerbaijan is endowed with rich oil and gas resources and is currently experiencing an oil boom. Azerbaijan's total energy production has increased almost three-fold from 27.9 million to 74.9 million oil equivalent mainly due to oil and gas production. The country's total energy consumption in 2009 was about 15.7 million tons, which means that a significant part of its production is exported (Ciarreta, 2012:pp.282-292).

Controlling the western side of the Caspian Sea, Azerbaijan holds a crucial position between Central Asia and Europe. Thus, by reconstruction of the economy, development and integration with globalized world, Azerbaijan, as one of the most important pillar has reached transmission lines allowing the export of energy sources. The most oil production was in 1941, which were 23.4 million tones till 2005 from the first date of production of oil. After the independence, reconstructing and entering the modification period reduced the oil production. But new steps and activities according to the "Agreement of The Century" increased the oil production. By the commencement of first oil production of Chiraq deposit in November 1997, the petrol production increased in 1998. Oil production was 15.3 million tons in 2003, 15.5 million tons in 2004, 22.2 million tons in 2005 and 32.3 million tons in 2006. With the amount of oil production in 2006 Azerbaijan put behind the oil production record of 1941 which was 23.4 million tons. The amount of oil production was 41.7 million tons in 2007 .Heavily dependent on the oil sector, the State Oil Company of Azerbaijan Republic (SOCAR) was created to efficiently benefit from the abundance of hydrocarbon resources in the respective sector of the Caspian Sea (Aras, 2013:pp.79-81).

The Shah Deniz Phase 2 project is expected to go into production in late 2018, and to start exporting to Europe in late 2019. Of the $16 \mathrm{bcm} /$ year of output, $6 \mathrm{bcm}$ will be sold to Turkey and $10 \mathrm{bcm}$ to Europe (including $1 \mathrm{bcm}$ each to trading companies in Greece and Bulgaria, and $8 \mathrm{bcm}$ to Italy and adjacent hub markets) (Shah Deniz major sales agreements..., 2013).

In addition to Shah Deniz, there are several offshore Caspian fields and exploration prospects that could increase Azerbaijan's gas production in the 2020s. One field, Absheron, has been declared commercial (but is yet to achieve FID) under a PSA (with Total as operator, GDF Suez, and SOCAR); production is expected to start in 2021, with 3-5 bcm/year in the initial phase. Beyond that there are other fields and exploration prospects that could be developed under PSAs or joint ventures, subject to exploration success and/or appraisal drilling.

SOCAR officials have projected an increase in production to 40-45 bcm of sales gas by 2025; (Scalability as Drawn, 2012) this assumes 9-14 bcm/year of gas from the new offshore projects by that date and must therefore be regarded as a maximum level. It seems likely that there would be a call on some of this gas from Azerbaijan's domestic market, and from Georgia. We estimate that $3-8 \mathrm{bcm} /$ year of additional gas could become available for export to Europe at some point in the 2020s.

\subsection{Kazakhstan and Uzbekistan}

Holding the greatest share of Caspian oil in its national sector, Kazakhstan's foreign policy is influenced by its dependence on Russian Federation as a primary energy transit route. Additionally, the growing inflow of FDI from China signals the rising importance of cooperation with the east. Due to these vast energy resources in possession, Kazakhstan`s decision on energy export routes is highly important for the (in) stability of the current power game in the Caspian.

Uzbekistan is a major gas producer (50-60 bcm/year in recent years), and Kazakhstan an expanding one (about 
$12 \mathrm{bcm} /$ year in recent years, likely to rise to $20-25 \mathrm{bcm} /$ year in the 2020s). Most Uzbek and Kazakh gas is consumed domestically; small quantities (7-10 bcm/year from each) are exported to Russia; and both countries have concluded framework agreements, and some contracts, with China, providing for exports via the Turkmenistan-China pipeline, which started in 2013 from Uzbekistan. It is possible that Uzbek and Kazakh exports to Russia will fall in the 2020s, but there will be calls on this gas from China and from their domestic markets (Reducing European Dependence on Russian Gas..., 2014).

There are hypothetically three ways that Uzbek and Kazakh gas could reach the European market:

- Kazakh gas could be transported by pipeline across the Caspian Sea to Azerbaijan, and thence to Europe. But the volumes available are negligible (assuming that exports to China remain minimal, and exports to Russia cease, perhaps $10 \mathrm{bcm} /$ year at some point in the 2020s), and the trans-Caspian crossing would be longer than in the case of Turkmenistan. Such a prospect may therefore be disregarded, at least until a Turkmenistan-Azerbaijan pipeline has been completed.

- Kazakh gas could be transported through Russia to Azerbaijan and thence to Europe. The costs involved, and the fact that Russia would be required to transport the gas, mean that this prospect can be disregarded for the purposes of this paper.

- Kazakh and/or Uzbek gas could be transported via Russia, via existing pipelines, to European destinations. (Such sales were conducted, with the gas bought and resold by Gazprom and other Russian companies, from the mid 1990s to 2009.) (Pirani, 2012).

\subsection{Turkmenistan}

The European Southern Corridor strategy, Turkmenistan has been as a key piece. Turkmen gas could come from TransCaspian pipeline, envisioned to transfer Turkmeni gas to Azerbaijan via the Caspian sea, where it could easily connect to the pipelines heading for Europe. These plans also effectively bypass both Russian Federation and Islamic Republic of Iran, but their major downfalls are the bad relations between Turkmenistan and Azerbaijan over the demarcation of the Caspian basin. East-West pipeline, envisioned to connect south-eastern Turkmeni gas fields with the Caspian (also creating a gate-way for Turkmenistan to European markets).

For Iran, a closer relationship with Turkmenistan promised useful oil swap agreements and access to the potentially lucrative Turkish natural gas market. The related further step of reaching Europe through Turkey would have put both Iran and Turkmenistan on the map as competitors to Gazprom. Iran considered, therefore, the 6 BCM Korpedzhe (on the Caspian shore of Turkmenistan) to Kurt-Kui line as a useful first step. The line was funded by Iran, with Turkmen debt to be repaid through gas deliveries. Still, the line had immediate advantages for Iran. A new domestic line linking gas fields in the south to the populous and industrial north-west would have cost far more than the Korpedzhe to Kurt-Kui pipeline (Kandiyoti, 2008:pp.75-93).

Since then Beijing has emerged as Turkmenistan near monopolistic buyer-about 80 percent of Turkmen gas exports are now directed toward China. If the Turkmen authorities want to avoid total dependency on China, they will have to reopen discussion with Europe, but such a push does not appear likely to come either from Ashgabat or from Brussels in short term (Lazrelle and Mankoff, 2016).

I assume that the only likely Central Asian source for significant gas exports to Europe is Turkmenistan. With only Turkmenistan contributing significantly to any gas transport towards the EU, additional gas from Azerbaijan will most likely have to measure the necessary capacity utilization and economies of scale in order to make the EU's tapping of Caspian resources economically viable.

\subsection{Other external actors}

Other players from the international community have been able to enter the Caspian game rather successfully following the collapse of the Soviet Union. The three former Soviet Republics were in desperate need of technology and capital to exploit the hidden Caspian resources; the outside involvement was therefore seen as crucial for developing drilling and exporting capabilities and also distancing Azerbaijan, Turkmenistan, and Kazakhstan from the Russian Federation. The Caspian basin being landlocked is dependent upon pipelines and shipping through neighboring states to reach consumer markets. Upgrading old Soviet pipelines and constructing others became pivotal for the economic stability of the region and it also gave way to major strategic planning of these new pipeline routes. The three post-Soviet Caspian littoral states were not very powerful in regional, let alone global, terms. Newly independent, with weak militaries, barely functioning economies, and great prospects for domestic and external conflict, they were easy targets for other interested parties looking to exploit these circumstances

With regards to the transshipment of hydrocarbon to the international market, the importance of the interests and the state of political environment in countries such as Georgia, Armenia, Turkey, Uzbekistan, Afghanistan, India and Pakistan, commonly referred to as the Outer Circle, needs to be remembered.

At the beginning of the energy hype around the Caspian, Turkey felt they can exploit their culture (considering that the Azeris, Turkmen, Kazakhs, and Uzbeks are all Turkic peoples) and its status as a modern, successful state to gain major influence in the region. Unfortunately, this perception proved to be by far a too optimistic one; although Turkish construction firms seem to do well in securing businesses in the region, when it comes to investment and major energy projects, all Caspian 
Table 5 Import Dependency-All Fuels (\%)

\begin{tabular}{|c|c|c|c|c|c|c|}
\hline Import from extra EU & 1995 & 2000 & 2005 & 2010 & 2013 & 2014 \\
\hline EU -28 & 43.1 & 46.7 & 52.2 & 52.6 & 53.1 & 53.5 \\
\hline Index 1995 & 100.0 & 108.3 & 121.1 & 122.2 & 123.3 & 124.1 \\
\hline \multicolumn{7}{|c|}{ Intra and Extra-EU imports } \\
\hline $\mathrm{BE}$ & 80.8 & 78.1 & 80.1 & 77.9 & 77.4 & 80.1 \\
\hline BG & 55.9 & 46.0 & 46.7 & 39.6 & 37.7 & 34.5 \\
\hline $\mathrm{CZ}$ & 20.6 & 22.9 & 28.0 & 25.6 & 27.9 & 30.4 \\
\hline DK & 33.4 & -35.0 & -49.8 & -15.7 & 13.3 & 12.8 \\
\hline $\mathrm{DE}$ & 56.8 & 59.4 & 60.4 & 60.1 & 62.66 & 61.6 \\
\hline $\mathrm{EE}$ & 32.3 & 32.2 & 26.1 & 13.6 & 11.9 & 8.9 \\
\hline IE & 69.5 & 84.8 & 89.6 & 86.6 & 89.3 & 85.3 \\
\hline EL & 66.7 & 69.5 & 68.6 & 69.2 & 62.2 & 66.2 \\
\hline ES & 71.7 & 76.6 & 81.4 & 76.7 & 70.4 & 72.9 \\
\hline FR & 48.0 & 51.5 & 51.6 & 49.1 & 48.0 & 46.1 \\
\hline HR & 36.1 & 48.4 & 52.5 & 46.6 & 47.0 & 43.8 \\
\hline IT & 81.9 & 86.5 & 83.4 & 82.6 & 76.8 & 75.9 \\
\hline $\mathrm{CY}$ & 100.5 & 98.6 & 100.7 & 100.8 & 96.4 & 93.4 \\
\hline LV & 70.4 & 61.0 & 63.9 & 45.5 & 55.8 & 40.6 \\
\hline $\mathrm{LT}$ & 63.1 & 59.4 & 56.8 & 81.8 & 78.3 & 77.9 \\
\hline LU & 97.7 & 99.6 & 97.4 & 97.1 & 97.0 & 96.6 \\
\hline $\mathrm{HU}$ & 47.9 & 55.2 & 63.1 & 58.2 & 52.1 & 61.7 \\
\hline MT & 104.8 & 100.3 & 100.1 & 99.0 & 104.1 & 97.7 \\
\hline NL & 20.0 & 38.1 & 38.0 & 30.3 & 26.1 & 33.8 \\
\hline $\mathrm{AT}$ & 66.4 & 65.4 & 71.6 & 62.8 & 61.6 & 65.9 \\
\hline PL & -1.2 & 9.9 & 17.2 & 31.3 & 25.6 & 28.6 \\
\hline PT & 85.3 & 85.1 & 88.6 & 75.1 & 72.9 & 71.6 \\
\hline RO & 30.3 & 21.8 & 27.6 & 21.9 & 18.5 & 17.0 \\
\hline SI & 50.9 & 52.8 & 52.5 & 48.6 & 46.9 & 44.6 \\
\hline SK & 68.5 & 65.6 & 65.3 & 63.1 & 59.2 & 60.9 \\
\hline FI & 53.6 & 55.1 & 54.2 & 47.8 & 48.5 & 48.8 \\
\hline SE & 38.9 & 40.7 & 36.8 & 36.6 & 31.6 & 32.1 \\
\hline UK & -16.4 & -16.9 & 13.4 & 28.4 & 46.4 & 45.5 \\
\hline
\end{tabular}

states seem to prefer the Russian Federation, American or European investors. An important aspect for Turks is the BTC pipeline, which connects Turkey directly to the Caspian region, although most of the country`s energy needs are still met through pipelines coming from the Russian Federation, most notably the Blue Stream. But, as it always is with the unpredictable strategic gaming in the Caspian, with the suspension of the Nabucco (Nabucco- West) and recently, the South Stream Project, it has become evident that Turkey could play a much more crucial role in the future of pipeline diplomacy. For now, both the EU and Russian Federation are entertaining themselves with a dream of a gas route through Turkey: EU sans Russian Federation, with a starting point in Azerbaijan and Russian Federation with a stream of gas flowing from Russian Federation fields, through Greece and Turkey. We have yet to witness which Southern Corridor strategy will be implemented. What is clear, though is that Turkey gained greatly in her starting position because of the zero-sum gaming process between Russian Federation and the EU, so her expectations of being an important (pivotal) transit country can become a reality in the near future.

\section{The EU'S Energy Import Dependency}

In 2011, the EU-27 imported about 83 per cent of its crude oil, 64 per cent of natural gas and 47 per cent of its coal demand. European Commission 2011 (Directorate general for energy, key figures, 2015). 
Table 6 Gas demand scenarios for those countries which are - and are likely to continue to be - highly dependent on Russian gas (with an SCI exceeding 30) up to 2030.

\begin{tabular}{|c|c|c|c|c|c|c|}
\hline & \multirow{2}{*}{$\begin{array}{l}\text { Gas demand in } \\
2013\end{array}$} & \multirow{2}{*}{$\begin{array}{l}\text { Russian gas } \\
\text { imports in } 2013\end{array}$} & \multicolumn{4}{|c|}{ Gas demand projections } \\
\hline & & & 2015 & 2020 & 2025 & 2030 \\
\hline \multicolumn{7}{|c|}{ Central European countries } \\
\hline Austria & 8.53 & 4.79 & 8.53 & 7.54 & 7.60 & 7.11 \\
\hline Czech Republic & 8.47 & 7.27 & 8.08 & 8.69 & 8.68 & 9.94 \\
\hline Slovakia & 5.81 & 5.06 & 4.72 & 4.86 & 6.19 & 7.66 \\
\hline Poland & 18.31 & 11.87 & 15.73 & 17.08 & 19.49 & 21.07 \\
\hline Hungary & 9.28 & 5.52 & 10.65 & 11.12 & 10.37 & 9.79 \\
\hline Total & 50.4 & 34.51 & 47.70 & 49.30 & 52.33 & 55.57 \\
\hline \multicolumn{7}{|c|}{ Baltic countries } \\
\hline Estonia & 0.68 & 0.64 & 0.34 & 0.38 & 0.41 & 0.43 \\
\hline Latvia & 1.73 & 1.01 & 1.83 & 1.93 & 2.05 & 2.13 \\
\hline Lithuania & 2.71 & 2.21 & 3.24 & 3.47 & 3.75 & 4.03 \\
\hline Finland & 3.48 & 3.22 & 2.33 & 2.35 & 2.72 & 3.06 \\
\hline Total & 8.6 & 7.08 & 7.74 & 8.13 & 8.92 & 9.65 \\
\hline \multicolumn{7}{|c|}{ South east European countries } \\
\hline FYROM & 0.16 & 0.09 & 0.12 & 0.12 & 0.12 & 0.12 \\
\hline Bosnia/Herzegovina & 0.19 & 0.18 & 0.26 & 0.27 & 0.29 & 0.30 \\
\hline Bulgaria & 2.59 & 2.67 & 2.89 & 3.03 & 3.14 & 3.29 \\
\hline Serbia & 2.52 & 1.84 & 2.30 & 2.30 & 2.30 & 2.30 \\
\hline Greece & 3.84 & 2.39 & 4.32 & 4.10 & 3.85 & 3.64 \\
\hline Total & 9.3 & 7.17 & 9.89 & 9.82 & 9.69 & 9.65 \\
\hline Grand Total & 68.3 & 48.76 & 65.33 & 67.25 & 70.95 & 74.86 \\
\hline
\end{tabular}

* converted to European units by reducing data in Table 1 by $7.97 \%$

Sources: 2013 demand for OECD countries from IEA Natural Gas (2014), Tables 3 and 8, pp. 8-9, 16-17;

Russian imports from Table 1; 2015-2030 projections from Honoré (2014).

Fossil fuel projections towards 2030 indicate that gas demand is most likely to rise while oil consumption will stagnate at the current high level (Europe's energy position, 2008). So far, Russia is the EU's most important energy supplier. Russia's share of EU gas.oil, and coal imports amount 34 per cent, 33 per cent and 26.2 per cent respectively. For the sake of comparison, Norway and Libya, the EU's second and third largest supplier of oil, account for about 15 and 10 per cent of imports. In the field of gas, Norway and Algeria contribute 31 and 14 per cent to the EU's demand (Gstol, 2015). Though EU energy imports are likely to further diversify as a consequence of increasing liquefied natural gas imports from Africa and Middle east, additional political steps towards diversification are necessary.

An important conclusion from Table 6 is that for the three groups of countries which are highly dependent on Russian gas, demand is expected to increase by less than $7 \mathrm{bcm}$ during the period 2013-2030: in Central Europe by $5.2 \mathrm{bcm}$, in the Baltic countries by $1.05 \mathrm{bcm}$, and in south-east Europe by $0.4 \mathrm{bcm}$. In 2030, total demand for gas in countries highly dependent on Russian gas in the Baltics and south-east Europe will be 19.3 bcm. In Central Europe, demand is much larger, particularly in Poland (which has significant domestic gas production and an SCI which is significantly lower than other countries in the region). Table 6 sets Turkey apart, as its gas demand is of a completely different order of magnitude and in the 2020s will approach the sum of all other countries. This data provides useful metrics for considering how much gas would be needed to replace Russian gas in the most dependent European countries up to 2030 .

\section{Alternative Sources of Gas Supply to Europe}

In the early 1970s, European indigenous production covered most of the region's gas demand. By 2013, due to faster growth rates of consumption and a decline in gas production since the early 2000s, it only accounted for around 57 per cent of demand (IEA Natural Gas Information Statistics, 2014).), European production is falling everywhere apart from Norway, and as a result, despite slow demand growth expected up to 2030, Europe will become increasingly dependent on imports. Two countries represented 70 per cent of the indigenous production in 2013 - Norway: $109 \mathrm{bcm}$ and the Netherlands: $86 \mathrm{bcm}$. These countries are also the two main sources of indigenous gas for the 
other European countries. Production from the UK continental shelf (UKCS) is still significant, at about $38 \mathrm{bcm}$, but it only represents about half of the national needs. Another 19 countries produced gas in 2013; this was used by their national markets, except for Denmark which exported small quantities. Table 7 shows scenarios for indigenous gas production in Europe for 2015, 2020, and 2030. Production is expected to decline from $282 \mathrm{bcm}$ in 2013 to about $266 \mathrm{bcm}$ in 2015 , mostly due to the limit imposed on production from the Groningen field in the Netherlands. By 2020, indigenous production could decline by another $20 \mathrm{bcm}$ as a result of sharper decline in the Netherlands, UK, and Germany. By 2030, European conventional gas production is expected to be about $172 \mathrm{bcm}$, a reduction of $110 \mathrm{bcm}$ compared with 2013 (Reducing European Dependence on Russian Gas..., 2014:p.12).

Table 7 also shows that the total is very dependent on the three largest producers, which account for $82-84$ per cent of the total throughout the period.

Table 7 Indigenous conventional gas production in European markets 2013-2030 (bcm)

\begin{tabular}{lllll}
\hline Country & 2013 & 2015 & 2020 & 2030 \\
\hline Norway & 109 & 109 & 110 & 100 \\
UK & 38 & 38 & 34 & 20 \\
Netherlands & 86 & 71 & 63 & 26 \\
Other & 49 & 48 & 39 & 27 \\
\hline TOTAL & 282 & 266 & 246 & 172 \\
\hline Norway/ & & & & \\
UK/ & 83 & 82 & 84 & 84 \\
Netherlands & & & & \\
as a \% of total & & & & \\
\hline
\end{tabular}

Sources: Danish Energy Agency (2014). Oil and gas production in Denmark and Subsoil Use, Annual report, p.19

www.ens.dk/sites/ens.dk/files/dokumenter/publikationer/

downloads/danmarks_olie-_og_gasproduktion_2013_uk.pdf

\section{The EU'S South European Gas Corridor: Options for Guaranteed Long-Term Gas Supplies}

The EU has been more active outside its borders in attempting to diversify its import supply routes and strengthen its ties with non-Russian suppliers in its neighborhood. This had led to a nascent 'energy diplomacy'. Already in 2008 the EU had launched a strategy to open up new gas import routes from Central Asia, the Caucasus and the Middle East - a project known as the Southern Corridor.

In June 2013, the Shah Deniz consortium and its leading stakeholders (the State Oil Company of Azerbaijan (SOCAR), BP, Statoil, Total, Lukoil, NICO and TPAO, Turkey's national energy company) concluded negotiations that have lasted over a decade, approving the Trans-Adriatic Pipeline (TAP) for the final leg of a pipeline bringing gas from the Shah Deniz field in the Caspian Sea to European markets. The consortium made a Final Investment Decision (FID) for stage 2 development of the Shah Deniz field, triggering plans to expand the South Caucasus Pipeline through Azerbaijan and Georgia, construct the Trans-Anatolian Gas Pipeline (TANAP) across Turkey and construct the TAP across Greece and Albania and into Italy. The first gas delivery to Europe (10 bcm/y) is scheduled for 2019 while plans to double this capacity are on the books. Another 6 $\mathrm{bcm} / \mathrm{y}$ will go to Turkey [33]. The development of the pipeline will mark a success for a long-mooted project that has been plagued with worries over long-term profitability in supplying Europe with additional gas. In order to diversify EU gas supply, and to provide Caspian suppliers with new export routes, several projects have been studied, re-evaluated, scrapped and resurfaced for the Southern Gas Corridor. Initial plans foresaw the construction of a $31 \mathrm{bcm}$ pipeline called Nabucco from Baku to the Bulgarian border and then to Baumgarten, Austria, but the Shah Deniz consortium's 2013 decisions will connect Baku to Greece via TAP and TANAP (20\% owned by Turkish BOTAS and TPAO and $80 \%$ by SOCAR). The European Commission's declared objective remains to eventually supply $10 \%$ of European gas demand via an enhanced Southern Gas Corridor (Implementation of the Communication..., 2013), but the current scenario would see the Corridor initially supply about $2 \%$ of Europe's demand. This may seem minor, but the countries receiving the gas - from Bulgaria to Greece are those that have the biggest energy security concerns due to reliance on Russian gas. The pipeline is also expected to instigate further infrastructure connections throughout the Balkans. The Commission has invested major efforts over the last decade in supporting first Nabucco, and now TAP/TANAP, granting the project exemption from third-party access regulation. Project costs have been estimated at $€ 3.9$ billion for TAP (Mombelli, 2013) €9 billion for TANAP, and almost $€ 30$ billion for the entire project, including further development of the Shah Deniz field (Guy, Ch., 2013). With British petrol committing its Shah Deniz resources to the EU's Southern Gas Corridor 10 billion cubic meters of Azerbaijani gas will eventually find its way to Europe by 2018 (Turkmen gas..., 2012).

The source diversification provided by the Southern Gas Corridor is not a panacea for European energy security but represents an important step in expanding Europe's energy frontiers towards the Caucasus and potential future partners in Iraq, Turkmenistan or Azerbaijan.

The Caspian and the Central Asian countries have a number of options to diversify their transport routes as well as export markets. While there is only the Turkmenistan-China pipeline to reach eastwards, three routes extend from Central Asia to the West: via the Caspian Sea, via Iran, and via Russia.

Nabucco-West vs.TAP: After years of fierce competition among Europe's energy giants, the developers of a major Azerbaijani natural gas field in the Caspian Sea recently picked 
the Trans-Adriatic Pipeline (TAP)_project over the Nabucco West project to transport Caspian natural gas to Europe. According to the estimated cost of the project is around $\$ 5$ billion (TAP clinches Azeri, 2014). If constructed, TAP, developed by Norway's Statoil, Switzerland's EGL and Germany's E.ON, will ship $10 \mathrm{bcm}$ of gas per year, with the option to increase the capacity up to $20 \mathrm{bcm}$. It will run through Greece and Albania, under the Adriatic Sea to southern Italy. The construction of TAP would provide the countries involved in this project, such as Greece and Albania, with a large inflow of foreign direct investment (FDI) and foster economic growth. TAP, Nabucco West, and South Stream: The Pipeline Dilemma in the Caspian Sea Basin and Its Consequences for the Development of the Southern Gas Corridor (Kusznir, 2013:p.3). Nabucco West is the shortened form of the so-called "Classic Nabucco" put forward a few years ago. "Classic Nabucco", one branch of which started from Georgian-Turkish border and was more than 3 thousand $\mathrm{km}$ in length, was planned for the transportation of 31 billion $\mathrm{m}^{3}$ of gas from Central Asia, South Caucuses and Middle East regions. The geopolitical situation in the above-mentioned regions, complete absence of export routes from these regions in the direction of Europe put the realization of that project under question (Nabucco West or TAP? 2013). Considering the gains accruing to Azerbaijan and Continental Europe from TAP and Nabucco-West, the model suggests that the Shah Denizfield's consortium as well as the European consumers would favor TAP over Nabucco-West at 2013, as the final route from the TurkeyEU border to the Central European markets. TAP ships the gas coming through TANAP from the Turkish-Greek border through Greece and Albania to Italy. TAP is based on a 2013 intergovernmental agreement between Albania, Italy and Greece (Offenberg, 2016:p.14). The advantage of the TAP project is that it connects the Caspian Sea and Turkey on one side and the European market on the other. Apart from its main route to Italy, which is the biggest European gas market after Germany, interconnectors can be built to Bulgaria from Greece, as well as a new pipeline to Montenegro and Croatia along the Adriatic coast from the tie-in in Albania, the Ionian Adriatic Pipeline (IAP).

Via the Caspian Sea (TCP). TCP carries Central Asian gas via an offshore pipeline under the Caspian Sea to its western coast, and from there the Southern Corridor (TANAP and TAP) delivers the gas to the Turkish and European markets. Turkmenistan benefits by 0.5 bn $€$ since TCP bypasses the current transit countries, i.e., Russia and Iran, and introduces a new transport route for westbound Central Asian gas. The power of Kazakhstan and Uzbekistan remains unchanged. They rely on Turkmenistan to access to TCP, and Turkmenistan's spare production capacity is more than enough to fill up the offshore pipeline's capacity. Turkey enjoys supply competition in its market as well as it strains it position on the route (0.bn $€)$. The suppliers serving the Turkish and European markets such as Russia, Iran and Norway suffer from supply competition with Turkmenistan.
However, Azerbaijan benefits from Turkmenistan's access to its export markets $(0.5$ bn $€)$ since it is the transit country on the route and controls Turkmenistan's access to the Southern Corridor. Although the EC supports TCP, Turkmen gas via TCP returns the European players (i. e., the Balkans, Continental Europe and UK) only $0.3 \mathrm{bn} €$ due to the transit countries on the route, and the European companies show little interest in the project. This finding implies that the EC may have overestimated TCP's strategic impact on the European players. Costing 0.5bn€ (Cobanli, 2014:pp.348-370). TCP is strategically viable for the non- European countries Turkmenistan, Azerbaijan and Turkey (1.5bn $€$ in total). Although Turkey has expressed its interest in Turkmen gas, the long-lasting dispute between Azerbaijan and Turkmenistan over the Kyapaz field in the Caspian Sea. There have also been suggestions that a similar submarine pipeline could be used to transport natural gas from Kazakhstan to Baku, where it could be fed into BTE, which could then be linked to Nabucco. However, continuing opposition from Russia and Iran currently appears likely to prevent any submarine gas pipeline across the Caspian from moving beyond a hypothesis (Staadmuller, 2012:p.190).

Via Iran (TTP) Linking Turkmenistan via Iran to the Southern Corridor. TTP benefits Turkmenistan by $0.3 b n €$. Again, the transit countries, in this case Turkey and Iran, collect most of the gains from the project. While Turkey enjoys supply competition in its market, Iran benefits from better access to the markets. TTP affects the rest of the players in an analogous manner to TCP. Iranian president Seyyed Mohammad Khatami stressed their interest in the construction of the gas pipeline Turkmenistan-Iran-Turkey-Europe $(3,900 \mathrm{~km}$ long carrying capacity of about $15 \mathrm{bcm}$ a year) and expressed their joint readiness to promote performance of the international consortium. In the nearest time, Turkmenistan intends to initiate gas extraction in the world's second gas field Galkynysh, whose reserves are evaluated from 13.1 to $21.2 \mathrm{tcm}$ of natural gas. In view of starting the development of such giant gas field, Ashkhabad is concerned about seeking new exports routes (Zhiltsov, 2016).

Iran has the world's biggest proven gas reserves, and Turkmenistan is ranked number four globally in terms of gas reserves. Together, the two neighboring countries, located in the richest swathe of land in the world in terms of energy resources, between the Caspian Sea and the Persian Gulf, have some 25\% of the world's gas. With the European Union and the United

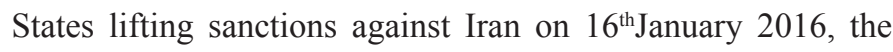
EU will gain access to a second major gas market in the world, beside Russia, and combined with the soaring LNG imports envisaged in the next few years, the EU's Energy Union's strategic goal to diversify Europe's energy supply could be reached.

After raising sanctions and normalizing the Tehran-US relationships and the extension of the new gas pipeline presently, supplying gas only to Iran as far as Turkey and further on to Europe could become soon reality. 
Via Russia: from South Stream to Turkish Stream. The south stream project is Russia's response to Nabucco. It was first announced in june 2007 when the Italian energy company Eni Paolo Scaroni and Gazprom of Russia signed a memorandum of understanding (MOU) which foresaw the construction of $900 \mathrm{~km}$ submarine pipeline from Druzhba on the Russian Black sea coast to the Bulgarian city of Varna. In Bulgaria, the pipeline will divide into two. The southern branch will run through Greece and under the Ionic sea to Italy, while the northwestern branch will run through Serbia and Hungary to the Baumgarten gas hub in Austria. The governments of Bulgaria, Serbia, Hungary, Greece and Italy have all signed agreements with Russia foreseeing the construction of South stream. On December 1, 2014, following a meeting between the Russian and Turkish presidents, president Putin and Gazprom CEO Alexey Miller announced that South Stream had been cancelled. The South Stream cancellation was accompanied by a Russian announcement that it would be replaced with pipelines of the same capacity to deliver gas across the Black Sea directly to Turkey. Of the $63 \mathrm{bcm} /$ year of capacity, $14 \mathrm{bcm} /$ year would replace the volume currently delivered to Turkey via Ukraine and the trans-Balkan pipeline, while the rest (approximately $50 \mathrm{bcm} /$ year) would be delivered to the Turkish-Greek border where Gazprom would set up a natural gas "hub" for Southern European customers (Stern, 2015:p.56)]. Turkish Stream proposals - both of which would create a new route in bringing (the same) Russian gas to Europe. For the EU, the energy security benefits of South Stream and Turkish Stream involving avoiding gas transit through Ukraine. Both routes diversify supply routes ... although not supply sources. Russians officials have stated that if the negotiations progress, gas could be delivered by the end of 2016. Turkish authorities, on the other hand, expect the project to continue for at least two and half years (De Micco, 2015).

\section{Conclusion}

As becomes apparent in the article, the Caspian littoral states .have many competing interests of a (geo-) political, economical and strategic nature. The five Caspian littoral states differ in terms of size, power projection capabilities and wealth in onand offshore natural resources. The two main Caspian littoral powers are Russia and Iran, both endowed with huge natural gas and oil resources on shore, and both not very well endowed with natural gas resources offshore in the Caspian Sea. The three small Caspian littoral states lack power projection capabilities, lack a diverse export market for natural resources (especially Turkmenistan and Kazakhstan) and are can not afford to go against the two large Caspian states where it concerns their 'red-lines'. As such, the vision of importing large quantities of natural gas or oil from the eastern side of the Caspian (Central Asia) to the Western side of the Caspian (Europe), is a task and will require a tectonic shift in EU foreign policy or alliances vis a vis third countries. The EU's energy security understanding revolved around primarily two objects: integration and diversification. The former of these meant expanding the internal EU market structures, this way also including external actors. This focus on transparent market rules and networks would strengthen Brussels, as it would increase access and availability of energy resources to the EU. Moreover, by interlinking energy infrastructure the Union would become more resilient to possible supply disruptions. In terms of the EU's diversification efforts, these were mainly related to attempts to establish new routes, seek to include new energy suppliers and finally to promote different energy types. All these three factors can be seen as having the same fundament in the EU energy thinking; as too large dependence on any one of these would constitute an energy security risk. Caspian basin and Central Asian countries played a role in both of the EU concerns. By integrating the Central Asian energy producing states into the EU network Brussels could formalize and institutionalize energy relations with the region. Consequently, this would turn Caspian countries into a stable supplier of energy to the EU, and the EU into a stable market for those countries. Moreover, the EU-Caspian energy structure could become a counterweight to Russia, hereby seeking to "calm" Russia down. Related to these points, Caspian countries were also an alternative for Brussels as a possible area of diversifying EU energy imports.

As things stand now, the geographical limits dictate three possible or already realized options of shipping Eastern Caspian energy resources to the Western Caspian. The first one is a legacy of the Soviet Union: Central Asian and Caspian energy resources being shipped through Russian territory and pipelines, to Europe. This is already the status quo. The second option is to build trans-Caspian pipelines, pipelines for the transport of gas and oil, from the Eastern sea beds of the Caspian, to the Western sea beds of the Caspian, to s hip the onwards to Europe. Thirdly, the 'southern route', piping Eastern Caspian (Kazakh and Turkmen) natural gas and oil through over land pipelines, via Iran, to Turkey and onwards to Europe. All three options have pitfalls, drawbacks and rewards. In this conclusion, I will focus on the 'path of least resistance'.

As it mentioned above the EU policy push toward supply diversification is to lessen the dependence and power of a potential major (geo-)political competitor and peer, Russia. Chiefly because of that reason, the first option (piping more Caspian and Central Asian energy to Europe through Russia) is not plausible and not a viable option. The second option, building under sea pipelines, cutting through the Caspian Sea, from East to West, has great challenges of a different nature. The biggest problem with this option, and in my opinion in surmountable is the tandem opposition of Russia and Iran. Both countries vehemently oppose the building of pipelines from the Eastern Caspian to the Western Caspian. For Iran, it would deprive it of a very large potential future market, the EU, which 
Iran could supply from it's more than ample gas reserves. For Russia, it would not only deprive it of a 'potential future market', it would undermine current gas delivery volumes, return on investment on already constructed pipelines. That makes both countries ready to do everything in their power to obstruct such a pipeline.

The third and final option is the southern route, piping the energy overland, from the Eastern Caspian, through Iran, to Turkey and onwards to the EU. This is the path of least resistance.

There are already pipelines between Turkmenistan and Iran and between Iran and Turkey. Although those pipelines don't have nearly enough capacity, parallel lines can be built. Routing through Iran solves two crucial problems. Firstly, it lessens dependence on Russian (routed) energy supplies. As such, it gives the captive Turkmen and Kazakh export markets a big breather. Their oil and gas can even be sold through the Persian Gulf ports. Secondly, it solves the insurmountable problem of double/tandem Russian-Iranian opposition to Caspian Sea pipelines. The EU has enough power to deal with Iran (mostly economically), but less with Russia. Iran has a population of 80 million and cultural, historical links to the other Caspian littoral nations. Also, it give those small countries a viable alternative vis a vis Russia, in order to balance their foreign relations. As such, this EU policy, if executed well, could be a two birds with one stone: not only lessen dependence on Russian gas/ oil (transit), but also to lessen Russia's influence in the littoral nations. That will force Russia to negotiate better prices in the future. As a side-bonus: Iran would be invested in behaving itself in the region and even in the middle east. Because being a reliable transit country for the first few years, would make EU policy heads open toward purchasing large quantities of Iranian gas, running along parallel lines, in the future. So it could potentially be three birds in one stone.

What is evident is that EU dithering in making actual progress will weaken it's hand and strengthen that of Russia, and increase alternatives for the Central Asian states.

The complex set of competing geographical, (geo-) political and economical interests of the littoral Caspian states and the competing interests of the two main littoral Caspian powers, Russia and Iran, necessitate a comprehensive energy strategy and policy by the EU. Iran with huge energy resources and an unparalleled strategic position in Central Asia and the Persian Gulf, wants to be a major transit route in the energy scene, it needs to rethink its policy towards the West.

\section{References}

2013 demand for OECD countries from IEA Natural Gas. (2014). 2015-2030 projections from Honoré. 8-9, 16-17.

An EU Strategy for relations with Iran after the nuclear deal (2016). [Online]. Available from: http://www.europarl.europa.eu/RegData/etudes/ IDAN/2016/578005/EXPO_IDA(2016)578005_EN.pdf [Accessed: 18th March 2015]

Aras, O. N., Süleymanov, E., Huseynov, R. (2013). The Importance of Azerbaijan's Energy Revenues in its Exports Volume and the Effects on the National Economy. International Journal of Business and Social Science. 4(6), pp.79-81.

Atlantic Council. (2012). European Energy Security: Southern gas corridor on the move. [Online]. Available from: http:/www.css.ethz.ch/en/services/ digital-library/articles/article.html/150937/pdf [Accessed: 16th March 2016]

Bajrektarevic, A. H. (2003). The Caspian Basin: Legal, political and security concerns, pipeline diplomacy and implications for EU energy security. (AWP No. 149) [Online]. Available from: https://www.econstor.eu/ handle/10419/145385 [Accessed: 2th February 2016]

Ciarreta, A., Nasirov, S. (2012). Development trends in the Azerbaijan oil and gas sector: Achievements and challenges. Energy Policy. 40, pp. 282 292. https://doi.org/10.1016/j.enpol.2011.10.002

Cobanli, O. (2014). Central Asian gas in Eurasian power game. Energy Policy. 68, pp. 348-370. https://doi.org/10.1016/j.enpol.2013.12.027

Crandall, M.S. (2006). Energy, Economics, and Politics in the Caspian Region: Dreams and Realities, Praeger Security International, Westport.

Croissant, M.P., Aras, B. (1999). Oil and Geopolitics in the Caspian Region. Praeger Publishers, Westport.

De Micco, P. (2015) Changing pipelines, shifting strategies: Gas in south-eastern Europe, and the implications for Ukraine. [Online]. Available from: http://www.europarl.europa.eu/RegData/etudes/IDAN/2015/549053/ EXPO_IDA(2015)549053_EN.pdf [Accessed: 19th April 2015]

Dekmejian, R. H., Simonian, H. H. (2003). Troubled Waters: The Geopolitics of the Caspian Region. I.B. Tauris, New York.

Dekmejian, R. H., Simonian, H. H. (2003). Troubled Waters: The Geopolitics of the Caspian Region. I.B. Tauris, New York.

Directorate general for energy, key figures. (2015). [Online]. Available from: http://ec.europa.eu/energy/observatory/countries/doc/key_figures.pdf [Accessed: 27th February 2013]

Europe's energy position. Past and present. (2008). European Commission. [Online]. Available from: http://eu.europea/energy/publications/ doc/2008_moe_maquette.pdf [Accessed: 17th March 2014]

Gstol, S., Lannon, E. (2015). The neighbors of the European Union's neighbors diplomatic and geopolitical dimensions beyond the European neighborhood policy. The Caspian Sea region: struggle for resources.

Guy, Ch., Dombey, D. (2013). Total and Statoil pull out of TANAP gas pipe deal, Financial Times. [Online]. Available from: https://www.ft.com/content/2d2e749a-666d-11e3-8675-00144feabdc0 [Accessed: 20th April 2016]

Hassanzadeh, E. (2014). Iran's natural gas industry in the post-Revolutionary period: Optimism, scepticism and potential. OIES/OUP, Oxford.

IEA (International Energy Agency) (2010). Gas Trade Flows in Europe. [Online]. Available from: http://www.iea.org/gtf/index.asp [Accessed: 15th March 2014]

IEA Natural Gas Information Statistics. (2014). [Online]. Available from: http://www.oecd-ilibrary.org/energy/data/iea-natural-gas-information-statistics_naturgas-data-en [Accessed: 13th February 2015] 
Implementation of the Communication on security of energy supply and international cooperation and of the energy Council conclusions of November 2011. (2013). http://eur-lex.europa.eu/legal-content/EN/ALL/?uri=CELEX\%3A52013DC0638

Kandiyoti, R. (2008). What price access to the open seas? The geopolitics of oil and gas transmission from the Trans-Caspian republics. Central Asian Survey. 27(1), pp. 75-93. https://doi.org/10.1080/02634930802221232

Kapitonov, I. A., Taspenova, G. A., Meshkov, V. R., Shulus, A. A. (2017). Integration of Small and Middle-sized Enterprises into Large Energy Corporations as a Factor of Business Sustainability. International Journal of Energy Economics and Policy. 7(2), pp. 44-52. URL: http://www.econjournals.com/index.php/ijeep/article/download/4040/2739

Kubicek, P. (2010). Energy Politics and the Geopolitical Competition in the Caspian Basin. Journal of Eurasian Studies. 4 (2), pp. 171-180. https://doi.org/10.1016/j.euras.2013.03.007

Kusznir, J. (2013). TAP, Nabucco West, and South Stream: The Pipeline Dilemma in the Caspian Sea Basin and Its Consequences for the Development of the Southern Gas Corridor. Caucasus Analytical Digest. 47, pp. 2-8. URL: http://www.laender-analysen.de/cad/pdf/CAD-47.pdf

Laumulin, M. (2007). The geopolitics of XXI century in Central Asia. Kazakhstan Institute for Strategic Studies at the President, Almaty.

Lazrelle, M., Mankoff, J. (2016). The European Union in a Reconnecting Eurasia: Foreign Economic and Security Interests. CSIS, Washington, DC.

Mangott, G. (2010). EU Gas supplies security: Russian and EU perspectives, the role of the Caspian the Middle East and the Magheb countries. Research Report. 367, pp. 45-46.

Mombelli, A. (2013). TAP gas pipeline causes controversy. [Online]. Available from: http://www.swissinfo.ch/eng/scepticism-flows_tap-gas-pipeline-causes-controversy/36350416 [Accessed: 5th March 2015]

Nabucco West or TAP? (2013). [Online]. Available from: http://www.socarplus.az/en/article/231/nabucco-West-or-tap [Accessed: 4th May 2016]

Offenberg, P. (2016). The EU neighbourhood and the EU's security of supply with natural gas. Policy paper, 156, 14.

Pirani, S. (2012). Central Asian and Caspian Gas Production and the Constraints on Export. OIES, 69.
Pivariu, C. (2014). Geopolitics Nowadays: Significant Episodes 2011-2014. Pastel, Braşov.

Reducing European Dependence on Russian Gas: distinguishing natural gas security from geopolitics. (2014). OIES, 92, 24.

Reducing European Dependence on Russian Gas: distinguishing natural gas security from geopolitics. (2014). OIES, 92, 12.

Scalability as Drawn. (2012). Azerbaijan 2012: The Business Year. Baku

Shah Deniz major sales agreements with EU gas purchasers concluded. (2013). [Online]. Available from: http:/www.bp.com/en/global/corporate/ press/press-releases/shah-deniz-major-sales-agreements-with-European-gas-purchasers-c.html

Staadmuller, E., Bachmaan, K. (2012). The EU's shifting borders approaches and policy of the new neighbourhood. Policy paper, 190.

Staadmuller, E., Bachmaan, K. (2012). The EU's shifting borders approaches and policy of the new neighborhood. Working Paper, 191-192.

Statistical Review of World Energy (2009). [Online]. Available from: http:// www.bp.com/liveassets/bpinternet/globalbp/reports and publication/ststisticalenergyreview2009 [Accessed: 10th February 2016]

TAP clinches Azeri gas pipeline deal. (2014) Financial times. [Online]. Available from: https://www.ft.com/content/41a3c048-de4f-11e2-b99000144feab7de [Accessed: 15th September 2016]

Turkmen gas: through Caspian sea to Europe. (2012). Turkish weekly. [Online]. Available from: http://www.turkishweekly.net/news/141507/turkmen -gas-through-caspian-sea-to-Europe-html [Accessed: 23th February 2015]

Zimnitskaya, H., Von Geldern, J. (2010). Is the Caspian Sea a sea: and why does it matter? Journal of Eurasian studies. 2(1), pp. 1-14. https://doi.org/10.1016/j.euras.2010.10.009

Zhiltsov, S. S., Zonn, I. S., Kostianoy, A. G. (2016). Oil and Gas Pipelines in the Black-Caspian Seas Region. Springer International Publishing, Switzerland. https://doi.org/10.1007/978-3-319-43908-2 